【カテゴリーI】

\title{
実地震観測記録を用いた 2 棟の免震建物動特性の同定 SYSTEM IDENTIFICATION OF TWO BASE ISOLATED BUILDINGS USING SEISMIC RECORDS
}

\author{
古川忠稔*，伊 藤 雅 史**，小野聡子***，橘，英三郎**** \\ Tadatoshi FURUKAWA, Masashi ITO, Satoko ONO \\ and Eizaburo TACHIBANA
}

\begin{abstract}
In this paper, the procedure of system identification by prediction error method, using nonlinear restoring force model, is presented, and several system identifications of two base-isolated structures using two-directional recorded seismic response are carried out. In the system identifications, the restoring force of the base isolation system is assumed to consist of several piecewise restoring force models, including multiple shear spring model. As results of using trilinear multiple shear spring models, both the estimated hysteresis shapes and the time histories show good agreement with those obtained directly from the observed data.
\end{abstract}

Keywords: Base Isolation, Seismic Record, System Identification, Nonlinear Dynamic Systems, Multiple Shear Spring Model, Hysteresis Models, 免震、地震記録、システム同定、非線形動的システム、MSS モデル、履歴モデル

1.はじめに

免震建物の地震時応答において支配的なのは、通常免震部材の復 元力特性である。そこで、免震部材に用いられる積層ゴムアイソ レータやダンパーを対象として、静的加力実験だけでなく、動的ア クチュエー夕を用いた加振実験や振動台実験がこれまでにも数多く 実施され、地震波等の非定常波入力時の復元力特性についても様々 な知見が得られている。さらに、これらの結果から各種のモデルも 多く提案されている1) 10)。しかし、動的アクチュエータによる加 力実験では、軸力導入下での水平 2 方向同時入力が技術的にやや難 しいことや、振動台実験では装置規模から縮小モデルを用いた実験 となる等の制約が考えられる。

免震構造物の地震応答観測や振動実験記録を用いた研究成果も数 多くあるが11) 14)、設計クライテリアに近い領域での強震動時応答 観測記録が数少ないことや、観測データのチャンネル数の制限など に起因する同定計算の難しさなどにより、応答観測記録から個々の 免震部材や免震層全体の非線形復元力特性を推定する試みはこれま

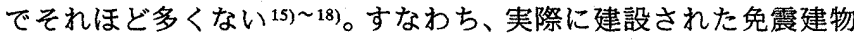
が、特に強震時に予想通りの挙動を示しているかについては、いま だ検証すべき余地が十分に残されていると考えられる。 本論文では免震建物の強震時応答観測記録を用い、免震層全体の
非線形復元力を具体的なパラメトリックモデルと仮定してシステム 同定を行う。パラメトリックモデルとしては通常免震部材のモデル 化に多く適用される区間線形モデルを用いることで、このモデルの 適用性に関する検証を行う。観測記録としては兵庫県南部地震本震 時に 2 棟の免震建物で得られた基礎上および建物応答記録を用い る。またシステム同定手法としては、非線形系同定のため著者らに よって拡張された、状態空間モデルによる予測誤差法 (Prediction Error Method with State-Space model: 以下PEM-SSと略記)を用い る。あわせて、本研究では地震時には兔震層が水平面内を複雑に振 動していることに注目し、免震部材の非線形復元力特性と水平 2 方 向移動の相互影響効果の両者に着目して同定計算を実施し、この影 響を考察する。

\section{2. 同定対象構造物}

本論で扱う同定対象構造物は、いずれも兵庫県南部地震の震央か ら約 $30 \mathrm{~km}$ 北東の神戸市北区に位置する松村組技術研究所免震棟 (以後、松村組免震建物と記す) と郵政省WESTビルの2棟である ${ }^{19}$ 。 同建物を写真 1，2に示す。また、観測記録の積分から得られた免 震層の変形軌跡を図 1 に示す。図 1 より、両者とも概ね $\mathrm{EW}$ 方向を 主軸として振動したことがわかる。以下各建物の紹介を行う。
* 大阪大学大学院地球総合工学専攻 学内講師・工博

** 三菱重工侏 工修

*** 有明工業高等専門学校建築学科 講師.$工$ 修

**** 大阪大学大学院建築工学専攻 教授 $\cdot$ 工博
Assistant Prof., Dept. of Global Architecture, Graduate School of Eng., Osaka Univ. Dr. Eng.

Mitsubishi Heavy Industries, Ltd., M. Eng.

Lecturer, Dept. of Architecture, Ariake National College of Technology, M. Eng.

Prof., Dept. of Architectural Eng., Graduate School of Eng., Osaka Univ., Dr. Eng. 


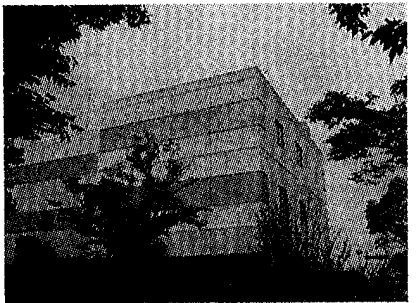

写真 1 松村組免震建物

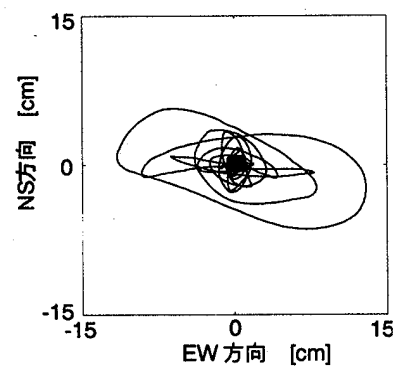

(a)松村組免震建物

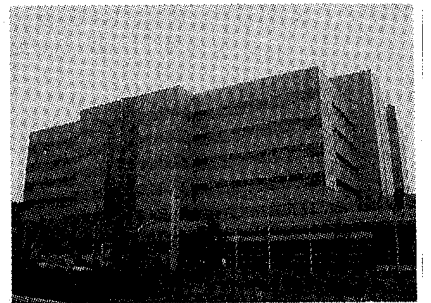

写真 2 郵政省WESTビル

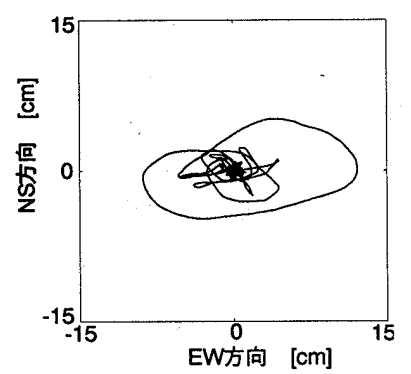

(b)郵政省WESTビル
図 1 免震層の変形軌跡

\section{1 松村組免震建物}

本構造物は $\mathrm{RC}$ 造 3 建てで、免震部材として高減衰積層ゴムを 8 基 備えており、上部構造は長辺方向 (以後EW方向と呼ぶ) が壁構造、短 辺方向 (以後 NS 方向と呼ぶ) は純ラーメン構造となっている。地震 計は基礎部で NS,EW,UD 各方向 1ch の計 3ch、1 階床上とR 階に各々 $7 \mathrm{ch}$ 、建物合計で $18 \mathrm{ch}$ 設置されており、比較的高密度の地震観測がな されている。兵庫県南部地震本震時には、基礎部で最大水平加速度 272[gal] の実測データが得られており、本観測データの解析から、兵 庫県南部地震の建物応答では、上部構造のロッキング応答やねじれ応 答は極めて小さかったことが伊澤ら 20)により報告されている。

\section{2 郵政省WEST ビル ${ }^{21)}$}

本構造物は、 $\mathrm{SRC}$ 造 6 階建て、建築面積 $8,563 \mathrm{~m}^{2}$ 、延べ床面積 $46,823 \mathrm{~m}^{2}$ の比較的規模の大きな免震建物である。免震部材には鉛プ ラグ入り積層ゴムを 54 基、天然ゴム系積層ゴムを 66 基、ループ状 鋼棒ダンパーを 44 基備えている。地震計は基礎部、1 階床上および 6 階床上に NS,EW,UD 各方向 $1 \mathrm{ch}$ づつ、合計 $9 \mathrm{ch}$ が設置されており、 兵庫県南部地震時は、基礎での最大水平加速度 $300[\mathrm{gal}]$ の実測デー タが得られている。

\section{3. 同定手法}

\section{1 PEM-SS の概要}

著者らは、線形多自由度モデルを表現するのに適した状態空間モデ ルを用いた予測誤差法を拡張し、非線形復元力を有する多入力多出力 系の同定手法を提案している22)。以下本手法の概略を示す。

(1)式の運動方程式で系が表されると仮定する。

$$
M \ddot{x}+R(\theta, t)=F(t)
$$

ここに、 $M, \ddot{x}, \boldsymbol{R}(\theta, t)$, と $\boldsymbol{F}(t)$ はそれそれ質量マトリクス、 加速度、復元力、および入力である。復元力モデルは非線形であり、 パラメータベクトル日により規定されるものとする。この復元力が 変位 $\boldsymbol{x}$ と速度 $\dot{\boldsymbol{x}}$ に比例する二つの復元力成分およびその残余項 $\boldsymbol{R}^{*}$ に分割可能であると仮定し(2)式を得る。

$$
M \ddot{x}+C(\theta, t) \dot{x}+K(\theta, t) x=F(t)-R^{*}(\theta, t)
$$

(2)式はいわば(1)式の非線形系と等価な線形系の運動方程式である が、減衰項と復元力項が時変形となる。この式は (3)式に示す線形時 変型状態空間モデルに変換できる。

$$
\dot{\boldsymbol{x}}=\boldsymbol{A}_{c} \boldsymbol{x}+\boldsymbol{B}_{c} \boldsymbol{u}
$$

ここに、

$$
\begin{aligned}
& \boldsymbol{x}=\left[\begin{array}{c}
\boldsymbol{x} \\
\dot{x}
\end{array}\right], \boldsymbol{A}_{c}=\left[\begin{array}{cc}
0 & I \\
-M^{-1} K(\theta, t, . .) & -M^{-1} \boldsymbol{C}(\theta, t, . .)
\end{array}\right] \\
& \boldsymbol{B}_{c}=\left[\begin{array}{cc}
0 & 0 \\
M^{-1} & -M^{-1}
\end{array}\right], u=\left[\begin{array}{c}
F(t) \\
R^{*}(\theta, t)
\end{array}\right]
\end{aligned}
$$

たとえば観測方程式が(4)式で表されたとすると

$$
\boldsymbol{y}=\boldsymbol{C}_{c} \boldsymbol{x}
$$

(3),(4)式の状態空間モデルについて、データサンプリング周期でモ デルを離散化し、あわせて状態ノイズと観測ノイズの雨者を考慮する ことで(5-1)、(5-2)式で示す様な”イノベーション型”の離散型状態 空間モデル ${ }^{23)}$ を得る。

$$
\begin{aligned}
& \boldsymbol{x}_{k+1}=A_{d}(\theta, t) \boldsymbol{x}_{k}+\boldsymbol{B}_{d}(\theta, t) u_{k}+\Gamma \cdot \boldsymbol{v}_{k} \\
& \boldsymbol{y}_{k}=C_{d} \boldsymbol{x}_{k}+\boldsymbol{v}_{k}
\end{aligned}
$$

ここで添え字 $k$ は時刻を示す。(5-1)式と(5-2)式より、(6)式で示さ れる観測量の一段階先予測值が得られる。

$$
\hat{\boldsymbol{y}}_{k+1}=C_{d}\left[\left(A_{d}-\Gamma C_{d}\right) \hat{x}_{k}+\Gamma y_{k}+B_{d} u_{k}\right]
$$

(6)式を用いて、予測誤差ベクトル $\varepsilon$ および予測誤差マトリクスEをそ れぞれ(7)式のように定義する。

$$
\varepsilon(k, \theta)=y_{k}-\hat{y}_{k}, E(\theta)=[\varepsilon(1, \theta), \varepsilon(2, \theta), \ldots, \varepsilon(N, \theta)]
$$

ここで、Nはデータセット長である。

モデルの復元力を規定するパラメータ日は、たとえば(8)式で規定され る予測誤差最小化規範 Jを満足する值として推定される。

$$
J(N, \theta)=\operatorname{det}\left[\frac{1}{N}\left\{E(\theta)^{x} \times E(\theta)\right\}\right] \rightarrow \min
$$

以上より PEM-SSは (8)式で示されるパラメー夕最適化問題となる。 本研究では、非線形最小 2 乗法の 1 種であるガウスーニュートン法 ${ }^{24)}$ を適用し最適パラメータ推定をおこなう。

\section{2 免震層復元カモテルとしてのMSS モデルの適用}

著者らはPEM-SS 法を用いて、以前にもWESTビルの動特性同定を 行っている25)。その際、対象建物を 1 方向多層せん断型モデルと仮定 し、上部構造を線形、免震層のみを区間線形モデルとして同定を実施 した。その結果、免震層復元力を区間線形モデルとし、粘性減衰を考 虑することで、応答の再現性の良い免震着復元力モデルが得られた。 しかし、このモデルで建物水平 2 方向の復元力を個別に同定すると、 同定された各次剛性等の推定パラメータ値が両方向で異なる結果とな ることがある。この原因として水平 2 方向移動の相互影響が考えられ るため、本研究はこの水平2方向移動の相互影響を考慮できる非線形 復元力モデルとしてMultiple Shear Spring(MSS)モデル20-27)を採用する。 MSSモデルは、水平面内に等価なせん断バネを等角度で配置し、その 


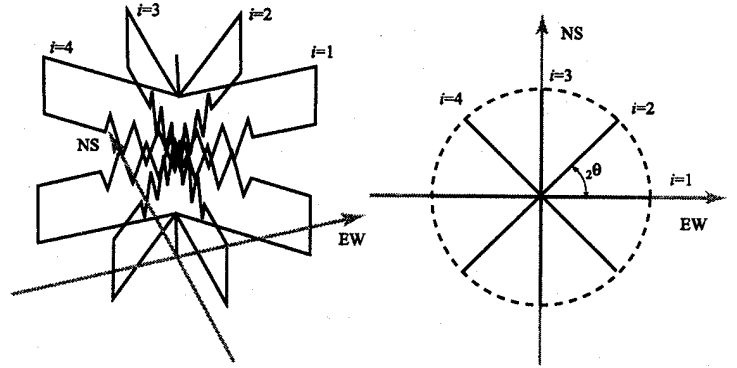

図 1.MSS モデル

合計としての性質が2方向の相互影響を考慮した形になる弾塑性モデ ルであり、免震部材としてのダンパーのモデル化にも用いられている。

MSSモデル内の各せん断バネ非線形履歴特性は、免震部材全体の骨 格曲線と、各バネ負担力の配分および耐力の関係から定まる。たとえ ば免震部材全体の骨格曲線をトリリニア型と仮定すると、図 1 に示す 一本のせん断バネの各次剛性、限界変位といったパラメータは、全体 骨格曲線のパラメー夕に基づいて(9),(10)式で定まる。

$$
\begin{aligned}
& k_{1}{ }^{\prime}=\frac{1}{\sum_{i=1}^{N} \cos ^{2}{ }_{i} \theta} k_{1}, k_{2}{ }^{\prime}=\frac{1}{\sum_{i=1}^{N} \cos ^{2}{ }_{i} \theta} k_{2}, \quad k_{3}{ }^{\prime}=\frac{1}{\sum_{i=1}^{N} \cos ^{2}{ }_{i} \theta} k_{3} \\
& X y_{1}{ }^{\prime}=\frac{\sum_{i=1}^{N} \cos ^{2}{ }_{i} \theta}{\sum_{i=1}^{N}\left|\cos _{i} \theta\right|} X y_{1}, X y_{2}{ }^{\prime}=\frac{\sum_{i=1}^{N} \cos ^{2}{ }_{i} \theta}{\sum_{i=1}^{N}\left|\cos _{i} \theta\right|} X y_{2} \\
& { }_{i} \theta=\frac{\pi}{N}(i-1) \quad(i=1,2, \ldots, N)
\end{aligned}
$$

ここで、 $k_{1}{ }^{\prime}, k_{2}{ }^{\prime}, k_{3}{ }^{\prime}$ は一本バネの一次剛性、三次剛性、三次剛性 であり、 $X y_{1}{ }^{\prime}, X y_{2}{ }^{\prime}$ は一本バネの一次折れ点変位、二次折れ点変位 である。同様に $k \sim_{3} k$ はそれぞれ全体骨格曲線の一次〜三次剛 性、 ${ }_{1} X y,{ }_{2} X y$ は一次および二次折れ点変位、また(11) 式の $\theta$ は 図 1 に示した $i$ 番目のせん断バネとEW方向とのなす角である。

MSS モデルでは、ある時刻 $t$ における EW, NS 方向の変位の増分 がそれぞれ $\Delta x_{e w} 、 \Delta x_{n s}$ となった場合、 $\mathrm{EW}, \mathrm{NS}$ 方向の復元力増分は (11) 式の ${ }_{i} \theta$ を用いて、(12) 式で求められる。

$$
\left[\begin{array}{c}
\Delta R_{e w} \\
\Delta R_{n s}
\end{array}\right]=\sum_{i=1}^{N} k(t)\left[\begin{array}{cc}
\cos ^{2}, \theta & \cos _{i} \theta \sin _{i} \theta \\
\cos _{i} \theta \sin { }_{i} \theta & \sin ^{2}{ }_{i} \theta
\end{array}\right]\left[\begin{array}{l}
\Delta x_{e w} \\
\Delta x_{n s}
\end{array}\right]
$$

ここに、 $k(t)(i=1,2, \ldots, N)$ は $i$ 番目のバネの時刻 $t$ における剛性である。 $k$ は骨格曲線から Masing 則に基づいて求め、時刻 $t$ までの各バネ方 向の変位及び速度履歴に依存して変化する。

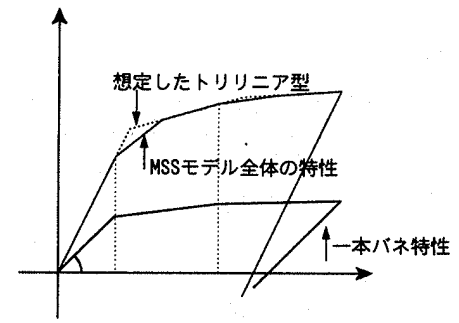

図 2 MSSトリリニアモデル骨格曲線
表 1 同定モデル

\begin{tabular}{l|l|l|l}
\hline & $\begin{array}{c}\text { 1本バネ復元力: } \\
\text { バイリニア }\end{array}$ & $\begin{array}{c}\text { 1本バネ復元力: } \\
\text { トリリニア型 }\end{array}$ \\
\hline
\end{tabular}

本研究では、同定用 MSS モデルとして等価せん断バネが 4 本のモ デルを用いる。このMSS モデルに対し、あるせん断バネ方向に変位 を与えると、各せん断バネが順に剛性低下を起こすため、実際の骨 格曲線は折れ点が多数現れ図 2 の様になる。

\section{4. 同定手法および結果}

\section{1 同定手法および同定モデル}

前述したように松村組免震建物はねじれ応答がほとんど生じてお らず、WEST ビルについては観測チャンネル数の制限によりねじれ応 答が分離できない。そこで本検討では個々のアイソレーターやダン パーの復元力を推定するのではなく、免震層全体の復元力を 1 つの 復元力モデルとして取り扱うこととし、松村組免震建物、WEST ビル とも表 1 に示す計 5 つのモデルを用いてPEM-SSによるシステム同定 を行う。なお表中個別モデルとは EW、NS の両方向の復元力パラメー 夕をそれぞれ個別に同定するモデルである。いずれの場合も、上部 構造はほぼ剛体的に挙動すると仮定し、パラメータ推定に用いる入 力量には基礎絶対加速度記録を、観測量には絶対加速度応答記録を 積分して求めた 1 階と基礎との相対速度応答記録および相対変位応 答記録を用いる。またデー夕長は 5000 個、サンプリング間隔は $0.01 \mathrm{sec}$ とする。なお、減衰はすべて免震層の履歷減衰のみと仮定し 粘性減衰は無視している。

\section{2 松村組免震建物の同定}

（1）水平 2 軸個別モデルによるパラメータ推定結果

パラメータの初期值と推定結果を表 2 に、パラメー夕推定値から 得られた骨格曲線を図 3 に示す。パラメータ推定値はEW、NS 方向で

表 2 パラメータ初期值および推定值 (水平 2 軸個別モデル)

\begin{tabular}{cc|c|c|c}
\hline & $\begin{array}{c}\text { 初期剛性 } \\
{[\mathrm{kN} / \mathrm{cm}]}\end{array}$ & $\begin{array}{c}2 \text { 次剛性 } \\
{[\mathrm{kN} / \mathrm{cm}]}\end{array}$ & $\begin{array}{c}\text { 折れ点変位 } \\
{[\mathrm{cm}]}\end{array}$ \\
\hline \multicolumn{2}{|c|}{ 初期值 } & 686.0 & 343.0 & 1.0000 \\
\hline \multirow{2}{*}{ 推定值 } & (EW-方向) & 705.0 & 126.6 & 0.5632 \\
\cline { 2 - 5 } & (NS-方向) & 694.3 & 87.7 & 0.8970 \\
\hline
\end{tabular}

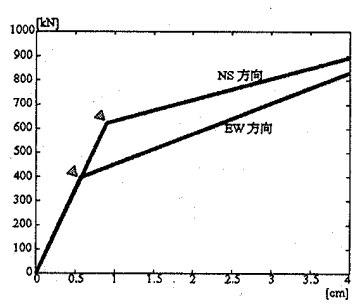

図 3 推定骨格曲線（水平 2 軸個別モデル） 
(a) EW 方向履歴曲線

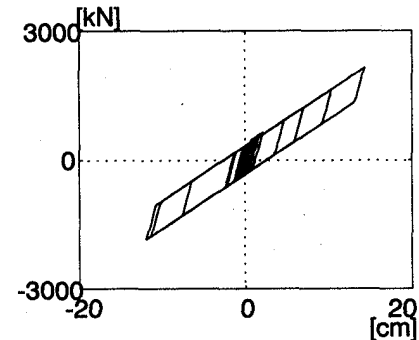

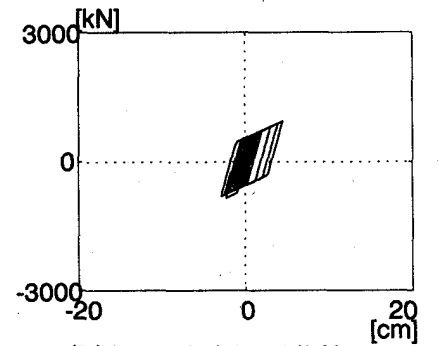

（b） NS 方向履歴曲線
図 4 履歴曲線推定結果（水平2 軸個別モデル)
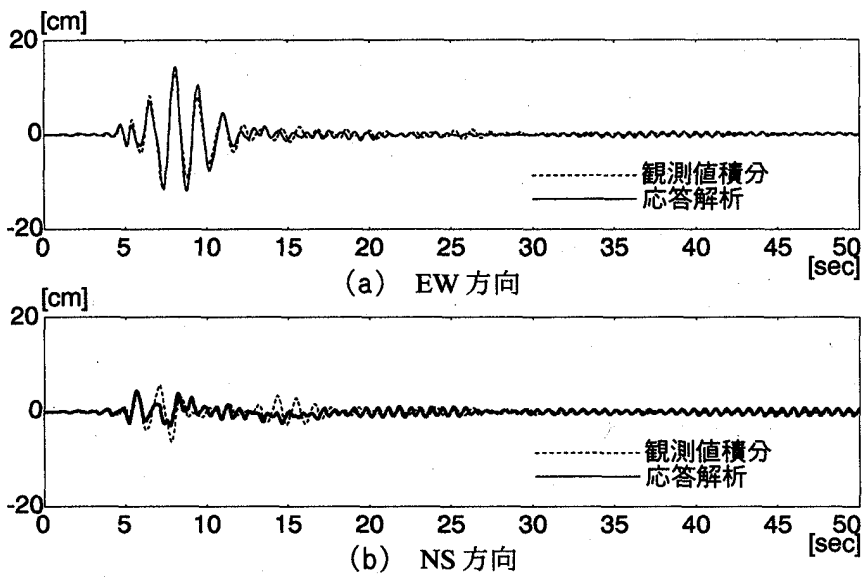

図 5 相対変位応答時刻歴波形 (水平 2 軸個別モデル)

異なるが、特に二次剛性、折れ点変位の違いにより図 3 の骨格曲線 形状もかなり異なっている。次にパラメータ推定値を用いた応答計 算より得られた復元力履歴曲線を図 4 に、応答計算結果の時刻歷と 観測值積分から直接的に求めた相対変位応答時刻歷との比較を図 5 に示す。推定された履歴曲線も骨格曲線と同様、EW、NS 方向でかな り異なる形状に推定された。時刻歷波形では EW 方向NS 方向ともに 6sec あたりまでは振幅、位相ともに観測波形と一致しているが、水 平二方向相互影響が強いと考えられる $6 \mathrm{sec}$ から $10 \mathrm{sec}$ あたりの主要 動付近では、特にNS 方向の波形の一致度が低い。

\section{（2）その他モテルによる同定結果}

個別モデル以外の同定計算における同定パラメータの初期値と推定 值を表 3 に示す。推定された骨格曲線を図 6 に示す。

バイリニアモデル、トリリニアモデルともに変位が $2.5 \mathrm{~cm}$ を超える 中変形領域と $0.5 \mathrm{~cm}$ 以下の微小変形領域では全てのモデルで概䄲同程 度の剛性と推定されている。一方 $0.5 \mathrm{~cm}$ 加ら $2.5 \mathrm{~cm}$ 付近の中小振幅領 域ではバイリニアモデルとトリリニアモデルの骨格曲線形状は異なっ ている。例えば0.5cm変形時ではトリリニアモデルに比ベバイリニア モデルの復元力はおよそ2倍に算定されており、動的解析でもこの振 幅領域の時刻歴波形は異なってくると考えられる。なお、バイリニア、 トリリニアとも独立モデルとMSSモデルの違いによる骨格曲線推定結

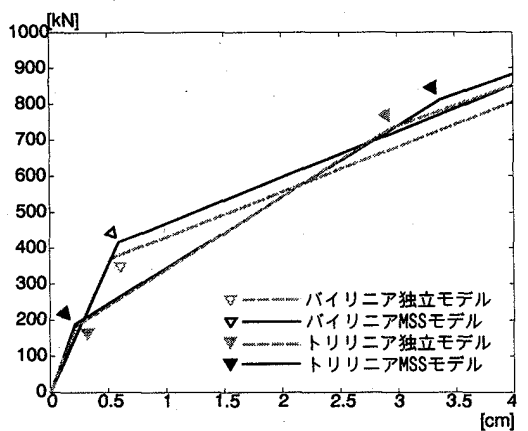

図6 推定骨格曲線 (その他モデル)

表 4 推定波形と観測波形との誤差の正規化 RMS值

\begin{tabular}{|c|c|c|c|c|}
\hline & \multicolumn{2}{|c|}{ EW方向 } & \multicolumn{2}{|c|}{ NS方向 } \\
\hline & 変位 & 速度 & 変位 & 速度 \\
\hline バイリニア独立 & 5.916 & 7.867 & 10.690 & 12.880 \\
\hline バイリ =アMSS & 5.198 & 7.179 & 11.330 & 12.840 \\
\hline トリリニア独立 & 4. 358 & 5.191 & 7.970 & 8.013 \\
\hline トリリ & 4.990 & 5.441 & 8.824 & 8.384 \\
\hline
\end{tabular}

果の違いは小さいため、水平 2 方向の相互影響が応答に及ぼす影響は それほど大きくないと予想される。

推定されたパラメータを用いて応答計算をした結果と観測デ一タの 直接積分により得られた 1 階相対変位応答時刻歴波形を図 7 に示す。 時刻歷波形の比較より、全てのモデルで主要動付近の応答再現性は良 好であり、概ね精度のよいパラメー夕推定が行われていると考えられ る。しかし、咩細に時刻歷波形を比較すると、主要動以降の振幅の小 さいあと摇れ部分ではバイリニアモデルよりトリリニアモデルの方が 推定された応答波形と観測記録とが精度良く一致している。特にNS 方向の相対変位応答時刻歴波形で15secあたりに見られる中振幅領域 ではバイリニアモデルの一致度が低い。この理由はバイリニアモデル は折れ点が一つであるため、大振幅時と特性の異なる微小変形時及び 中小振幅時の非線形復元力特性を表現できないが、トリリニアモデル は二つの折れ点を持つため、振幅の大きい領域に加えて振幅の小さい 領域でも高い精度で復元力特性を推定できるためであると考えられる。

次に、応答計算により得られた応答時刻歷と観測デー夕直接積分か ら得られた時刻歴間誤差の正規化RMS值を表 4 に示す。正規化は個々 の応答誤差RMSを最大振幅で除したものとし、これを\%表示している。 表中の正規化RMS值で比較すると、まずMSS、独立にかかわりなく バイリニア型モデルよりトリリニア型モデルの方が応答推定精度が良 いことがわかる。これより、小振幅から大振幅の応答を精度良く推定 するためには、バイリニア復元力よりトリリニア復元力モデルを用い たほうが良いと考えられる。また、変位、速度によらず、振動主軸で あるEW方向の応答に比べ、NS方向の応答推定精度が低下している。こ のことは水平2方向の復元力特性が何らかの原因により異なっている

表 3 パラメータ初期值および推定值 (その他モデル)

\begin{tabular}{|c|c|c|c|c|c|c|}
\hline & & 初期剛性 [kN/cm] & 2次剛性 $[\mathrm{kN} / \mathrm{cm}]$ & 3 次剛性 $[\mathrm{kN} / \mathrm{cm}]$ & 1次折れ点変位 $[\mathrm{cm}]$ & 2次折れ点変位 $[\mathrm{cm}]$ \\
\hline 初期值 & & 686.000 & 343.000 & - & 1.000 & - \\
\hline \multirow{2}{*}{ 推定値 } & バイリニア独立 & 703.900 & 125.000 & - & 0.528 & - \\
\hline & バイリニアMSS & 702.100 & 127.400 & - & 0.594 & - \\
\hline 初期値 & & 686.000 & 548.800 & 137.200 & 0.500 & 2.000 \\
\hline \multirow{2}{*}{ 推定值 } & トリリニア独立 & 826.600 & 201.500 & 113.000 & 0.223 & 2.950 \\
\hline & トリリニアMSS & 875.400 & 197.500 & 133.300 & 0.216 & 3.366 \\
\hline
\end{tabular}



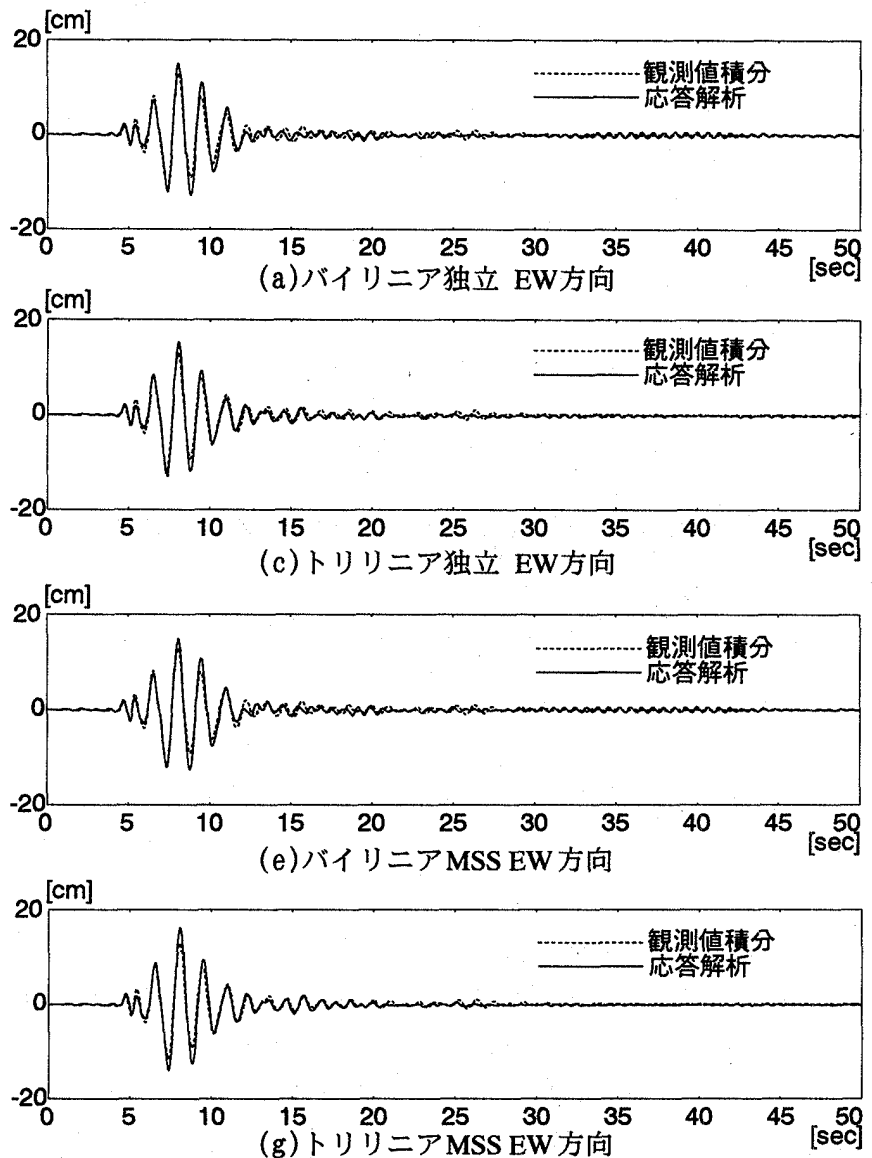

図 7，相対変位時刻歷推定結果

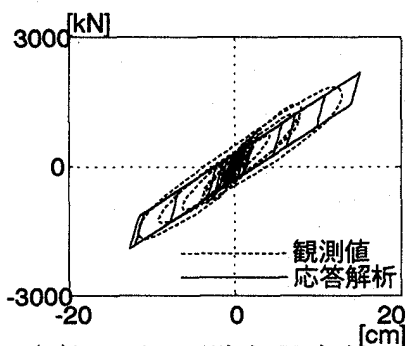

(a)バイリニア独立 EW方向

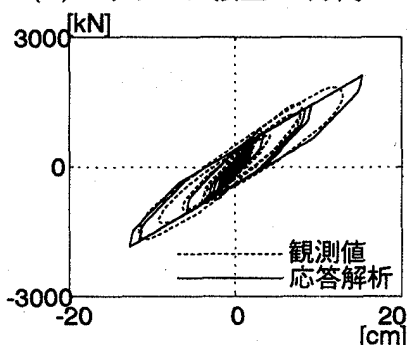

(c)トリリニア独立 $\mathrm{EW}$ 方向

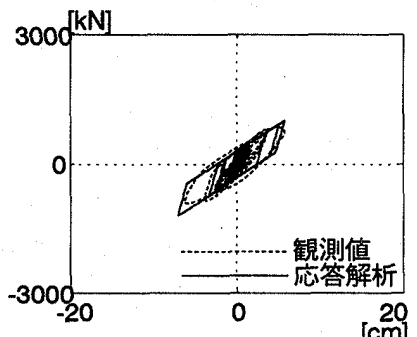

(b)バイリニア独立 NS方简

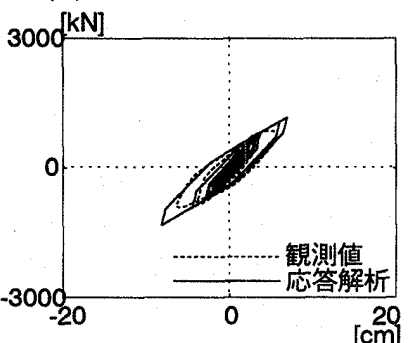

(d)トリリニア独立 NS方向
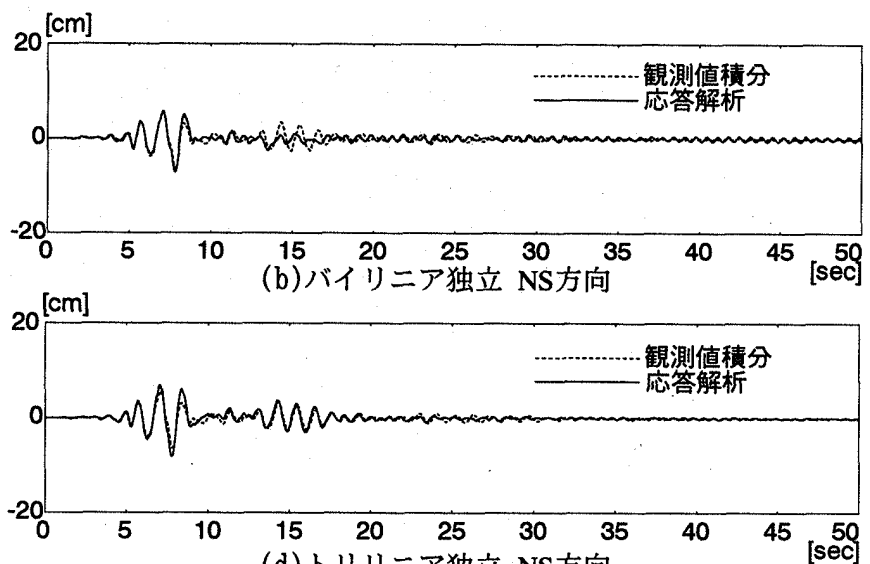

(d)トリリニア独立 NS方向
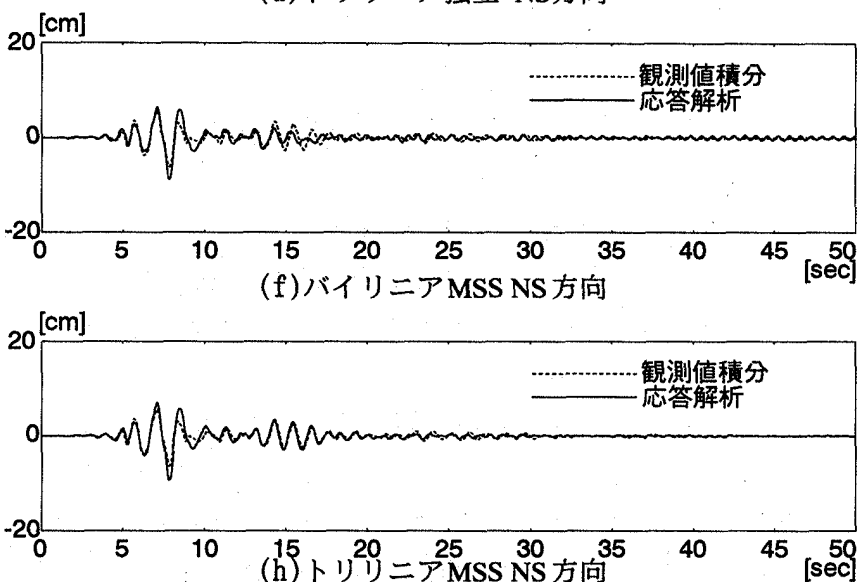

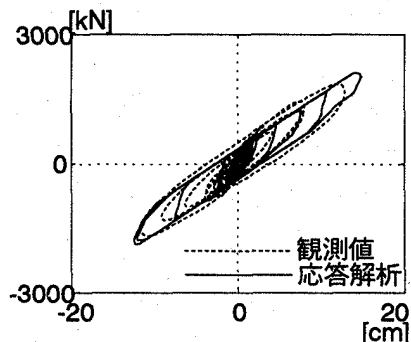

(e)バイリニアMSS EW方向 ${ }^{[\mathrm{cm}]}$

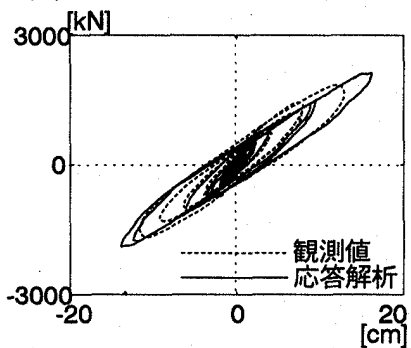

(g)トリリニアMSS EW方向

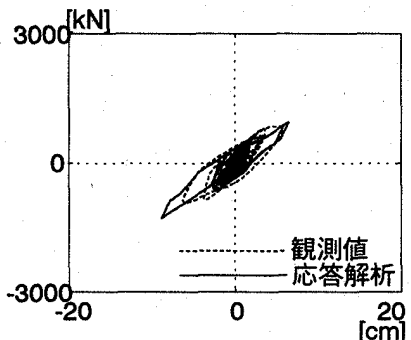

(f)バイリニアMSS NS方高

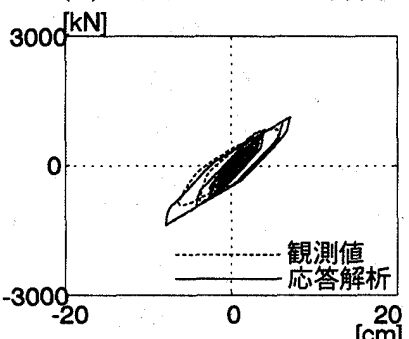

(h)トリリニアMSS NS方向

図8 履歴曲線推定結果

ことを示唆していると考えられる。しかし、同じトリリニア型におい ても、水平2方向相互影響を評価できるMSSモデルを用いた場合より も、水平2方向独立とした場合の方が推定精度が若干良いことを考虑 すると、この原因は免震部材の水平2方向変形の相互影響の影響であ ると断定することはできない。

次に、推定されたパラメータによる応答計算から求めた復元力履歴 曲線を図 8 に示す。図中には、復元力曲線の目安として斎藤ら ${ }^{14)}$ の手 法により直接的に推定した履歴曲線(図中観測値と記入、以後観測値
と呼ぶ）をあわせて記入している。

図8においてバイリニア独立(a),(b)とバイリニアMSS(e),(f)を 比較すると、EW,NSによらず独立モデルよりMSS モデルの方がより 滑らかな履歷形状となっており、観測値と近い形状となっている。 またトリリニアモデルとバイリニアモデルによる㠅歴曲線の比較に よると、トリリニアモデルでは折れ点変位が一つ増えることにより、 より滑らかな剛性の変化を表現できていることがわかる。

さらに、相対的に振幅が小さく相互影響がより大きく現れやすい 
表 5 パラメータ初期值および推定值（水平 2 軸個別モデル)

\begin{tabular}{cc|c|c|c}
\hline & & $\begin{array}{c}\text { 初期剛性 } \\
{[\mathrm{kN} / \mathrm{cm}]}\end{array}$ & $\begin{array}{c}2 \text { 次剛性 } \\
{[\mathrm{kN} / \mathrm{cm}]}\end{array}$ & $\begin{array}{c}\text { 折れ点変位 } \\
{[\mathrm{cm}]}\end{array}$ \\
\hline 初期值 & & 19600.0 & 3920.0 & 1.0000 \\
\hline \multirow{2}{*}{ 推定值 } & (EW-方向) & 24417.0 & 4467.5 & 0.6151 \\
\cline { 2 - 5 } & (NS-方向) & 24092.0 & 4294.7 & 0.3730 \\
\hline
\end{tabular}

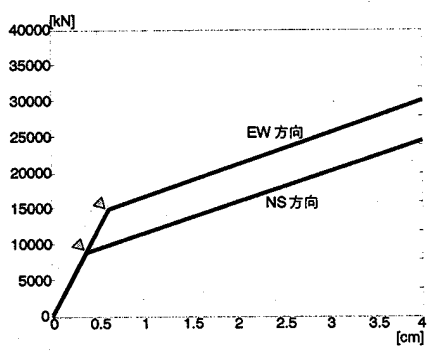

図 9 推定骨格曲線 (水平 2 軸個別モデル)

と考えられるNS 方向の履歴において、図(f)に見られるように、MSS モデルでは水平 2 方向相互影響による履歷形状の変化が生じている。 表 4 に示した誤差の RMS 值も、バイリニアモデルでは独立よりも MSS モデルの推定精度が高い。しかし、トリリニアモデルにおいて は、独立とMSSを比較しても履歴形状の変化があまり見られないこ とや、本検討ではトリリニアMSSよりもトリリニア独立モデルのほ うが推定精度が高かったことを考え合わせると、バイリニアMSS が バイリニア独立に比較して推定精度が高い理由は、MSS モデルが実 際には多数の折れ点を持つことによる効果と結論付けられる。

図 $8(\mathrm{c}),(\mathrm{d})$ および $(\mathrm{g}),(\mathrm{h})$ より、トリリニアモデルを用いて推定 された復元力履歴曲線は、観測值の履歴曲線と良く一致しているこ とがわかる。EW方向で $3.5 \mathrm{~cm}$ を超える大変形時の一致度が低い理由 は、トリリニアモデルでは二つ目の折れ点が $3.5 \mathrm{~cm}$ 付近でありそれ 以上の変形での剛性の変化を表すことができなかったためと考える。 さらに大きな変位に折れ点を持つ数学モデルを用いることにより大 変形時の復元力特性もさらに精度良く推定できると予想される。

\section{3 WEST ビルの同定}

\section{（1）水平 2 軸個別モテルによるパラメータ推定結果}

パラメー夕の初期值および推定值を表 5 に示す。また、推定され たパラメータにより決まる骨格曲線を図 9 に示す。

推定パラメータのうち剛性に関しては、一次剛性、二次剛性ともに EW方向NS方向とでほぼ同じ值に推定されたが、折れ点変位はEW方 向よりNS方向が小さく推定された。その結果、WESTビルにおいては、 大振幅領域では振動レベルの大きなEW方向の復元力が、振動レベルが 小さなNS方向より大きくなる様に同定されている。これは松村組免震 建物とは逆の傾向であり、水平2方向の相互影響のメカニズムが異な ることが予想される。

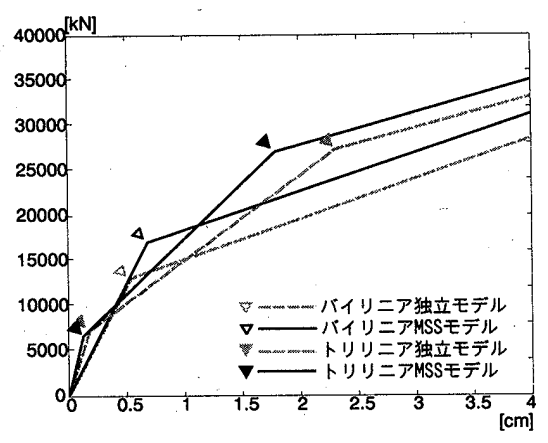

図10 推定骨格曲線(その他モデル)

表 6 推定波形と観測波形との誤差の正規化 RMS 值

\begin{tabular}{lcccc}
\hline & \multicolumn{2}{c}{ EW方向 } & \multicolumn{2}{c}{ NS方向 } \\
\hline & 変位 & 速度 & \multicolumn{1}{c}{ 変位 } & 速度 \\
\hline バイリニア独立 & 4.369 & 3.848 & 8.110 & 6.865 \\
\hline バイリニアMSS & 3.712 & 3.516 & 8.807 & 6.711 \\
\hline トリリニア独立 & 2.236 & 2.065 & 6.600 & 4.123 \\
\hline トリリニアMSS & 2.111 & 1.700 & 6.927 & 2.928 \\
\hline
\end{tabular}
RMS值/最大振幅 $\times 100[\%]$

\section{（2）その他モデルよよる同定結果}

個別モデル以外の同定計算における同定パラメータの初期値と推 定值を表 5 に、推定された骨格曲線を図 10 に示す。

図10より推定骨格曲線は、全ての同定モデルで大変形領域ではほ ぼ同じ傾きであることがわかる。しかし、変形がおよそ $2.0 \mathrm{~cm}$ 以下 の範囲では、剛性、折れ点変位ともにばらついており、その結果全 体的に骨格曲線が全てのモデルで異なっているように見える。特に 骨格曲線と横軸で囲まれる面積は各モデルにより異なり、各モデル により表現することのできる減衰性能には、かなりばらつきがある と考えられる。

推定されたパラメータを用いて応答計算をした結果と観測データ の直接積分により得られた 1 階相対変位応答記録を図 11 に示す。推 定波形と観測波形の誤差正規化 RMS 值を表 6 に示す。

推定パラメータを用いて計算した相対変位応答時刻歷波形は、観測 波形と良く一致している。これより全ての場合でパラメータ推定は、 高い精度で行われたと考えられる。表 6 に示したRMS 值の比較によ ると、トリリニアMSS モデルが最も波形の一致度が高いことがわか る。さらにバイリニアモデルの場合においても、独立より MSS モデ ルの方が誤差の正規化 RMS 值が減少していることから、本建物にお いては水平 2 方向独立モデルよりもMSS モデルを用いる方が同定モ デルとして適切であると考えられる。

次に、応答計算から求めた復元力履歴曲線と前述の手法により観 測記録から直接的に求めた履歴曲線（図中観測值と記入）を図 12 に 示す。推定されたパラメータを用いた応答計算により描いた履歴曲

表 5 パラメー夕初期值および推定值 (その他モデル)

\begin{tabular}{|c|c|c|c|c|c|c|}
\hline & & 初期剛性 [kN/cm] & 2 次剛性 $[\mathrm{kN} / \mathrm{cm}]$ & 3次剛性 $[\mathrm{kN} / \mathrm{cm}]$ & 1次折れ点変位 $[\mathrm{cm}]$ & 2次折れ点変位 $[\mathrm{cm}]$ \\
\hline 初期値 & & 19600.0 & 3920.0 & - & 1.00000 & - \\
\hline \multirow[b]{2}{*}{ 推定值 } & バイリニア独立 & 23982.0 & 4465.5 & - & 0.54491 & - \\
\hline & バイリニアMSS & 24860.0 & 4261.9 & - & 0.68571 & - \\
\hline 初期値 & & 19600.0 & 15680.0 & 1960 & 0.50000 & 2.0000 \\
\hline \multirow[b]{2}{*}{ 推定値 } & トリリニア独立 & 41505.0 & 9515.4 & 3428.3 & 0.17088 & 2.2946 \\
\hline & トリリニアMSS & 52984.0 & 12223.0 & 3593.1 & 0.12649 & 1.7897 \\
\hline
\end{tabular}



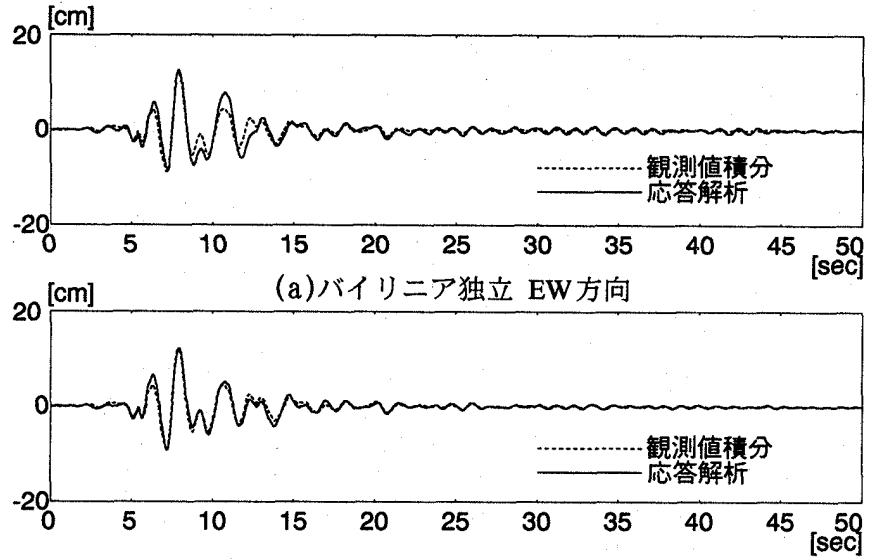

(c)トリリニア独立 EW方向
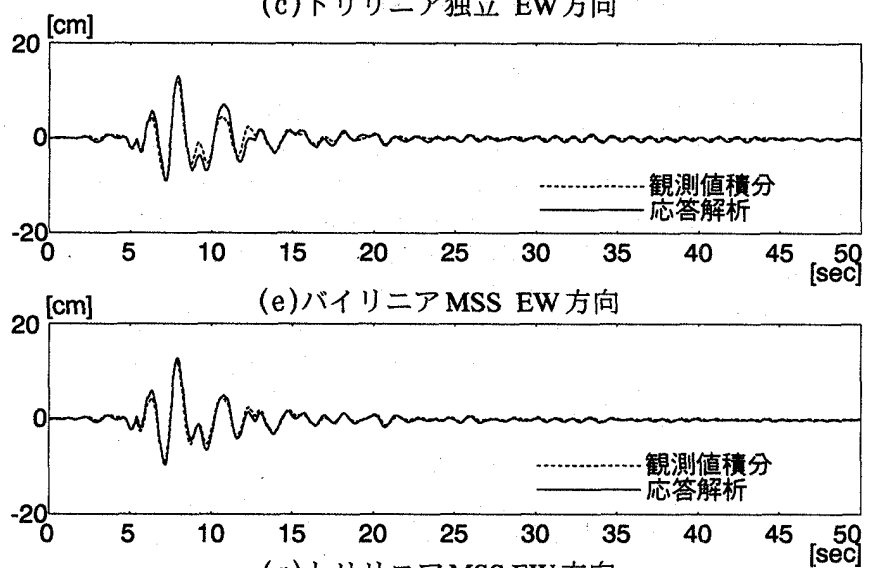

(g)トリリニアMSS EW 方向

図11 相対変位時刻歷推定結果

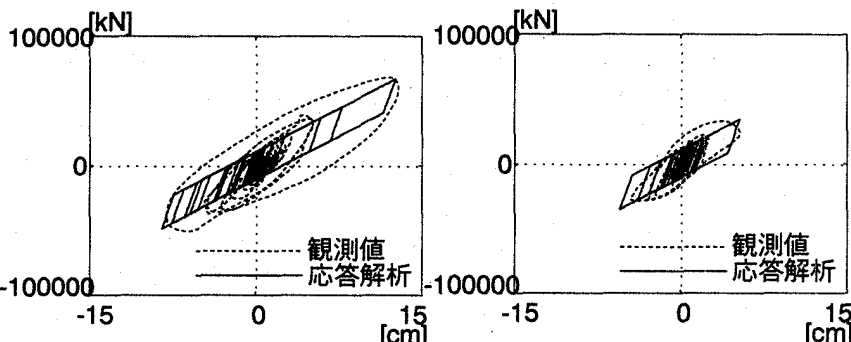

(a)バイリニア独立 $E W$ 方向 ${ }^{[\mathrm{cm}]}$ (b)バイリニア独立 NS方向

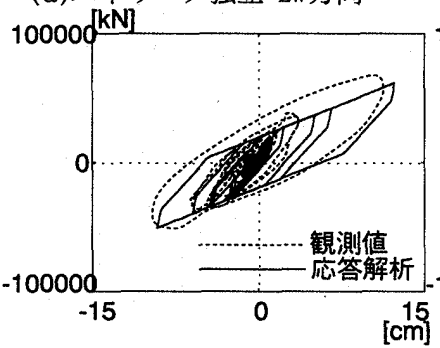

(c)トリリニア独立 EW方向 $10000[\mathrm{kN}]$

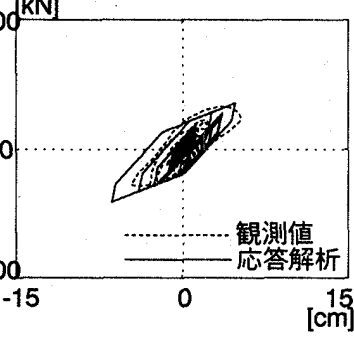

(d)トリリニア独立 NS方向

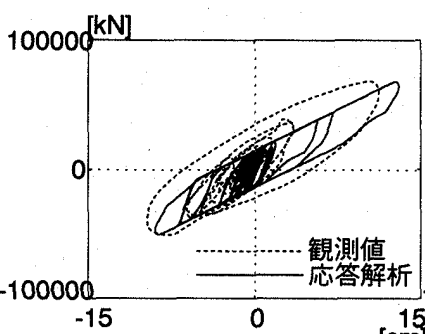

(e)バイリニアMSS EW方向 $[\mathrm{cm}$

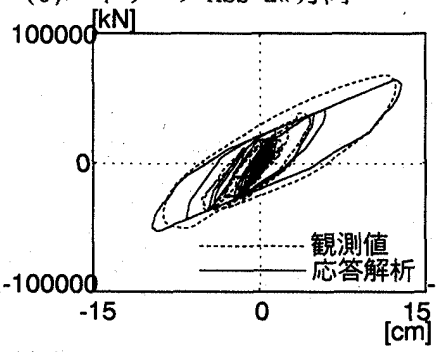

(g)トリリニアMSS EW方向

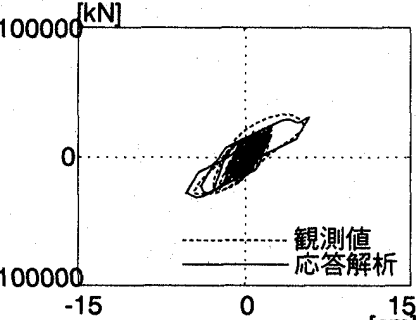

(f)バイリニアMSS NS 㘯宂

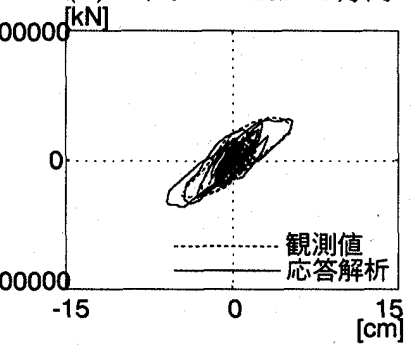

(h)トリリニアMSS NS方向

\section{図12 履歴曲線推定結果}

線の面積は、各モデルにより大きく異なる。

図 12 に示す $\mathrm{EW}$ 方向復元力履歴の比較から、トリリニアモデルで はバイリニアモデルに比べ履歴曲線の幅が広く減衰特性を大きく評 価していることがわかる。トリリニアモデルによる応答計算での正 規化 RMS 值がバイリニアモデルに比べ小さいことから、対象構造物 が持つ減衰特性はトリリニアモデルを用いたものに近いと言える。 また、独立モデルとMSS モデルの比較をおこなうと、特にNS 方向の 履歴曲線において、MSS モデルが独立モデルに比較してより観測值

の形状に類似していることや、もっとも相互影響が出やすいと考え られる最大振幅時近辺の履歴形状がより近いことから、MSS モデル の採用により水平 2 方向の相互影響を考慮することが、同定精度の 向上に寄与していると考えられる。ただし、MSS モデルのもつ特徵 である多数の折れ点の出現により、結果的に滑らかになった履歴曲 線形状が同定精度の向上に寄与している可能性もあるため、この問 題については今後更なる検討が必要であると考えられる。 


\section{5.まとめ}

松村組技術研究所、WEST ビルとも、上部構造を剛体と仮定し、表 1 に示す計 5 つの同定モデルを用いて免震層の動特性を同定した。 その結果、水平 2 軸個別モデル以外の各モデルでは、いずれのモデ ルを用いた場合も、時刻歴応答、復元力履歴曲線とも概ね良い再現 性をもっており、結果は妥当であると考えられる。また、推定され た時刻歷応答と観測デー夕直接積分の結果を比較すると、免震層の 復元力特性としては、バイリニアモデルよりもトリリニアモデルを 用いることにより、大振幅領域から小振幅領域までの応答再現性を 高めることができると考えられる。さらに、同定モデルの応答計算 から得られた履歴曲線と、直接的に推定された履歷曲線の形状比較 より、トリリニア型復元力モデルの場合の方がより再現性が優れて いると考えられる。また、MSS モデルの採用による水平 2 方向の相 互影響の効果は、ここで検討された 2 棟の免震建物のうち、WEST ビ ルでは同定精度の向上に寄与しているが、松村組免震建物では精度 向上に寄与しなかった。ただし、本検討で用いた 2 棟の免震建物は、 いずれも振動の主軸が概ねEW方向に平行であり、相互影響がそれほ ど顕著に表れにくい観測記録であることも考えられ、相互影響の詳 細な考察には、今後さらなる観測データの蓄積が必要であると考え られる。ただし、トリリニアMSS モデルがトリリニア独立モデルに 比較して同定精度が低下した松村組免震建物においても、その精度 低下は些少であり、免震層全体のモデルとしては、トリリニアMSS モデルの採用により、その微小変形領域と中変形領域での剛性の低 下を精度良く表すことができると考えられる。

なお、建築構造における強度上の安全性の観点から通常問題とな る、応答最大値再現性の観点で考えると、本検討では個別モデル以 外のいずれのモデルにおいてもそれほど差異はないことや、通常 様々な復元力特性を有する個々の免震部材で構成される免震層全体 をトリリニア程度の区間線形で十分モデル化可能であることから、 通常の免震建物の設計において、免震部材をバイリニア系でモデル 化することや、水平 2 軸を独立として解析することは概ね妥当であ ると結論づけることができる。

\section{参考文献}

1）日本建築学会 : 免震構造設計指針，日本建築学会，1993

2）藤田隆史, 鈴木重信, 藤田 聡: 建物免震用の高減衰積層ゴムに関する研 究 (第 1 報, 履歴復元力の基本特性と解析モデル)，日本機械学会論文集 (C編),56巻523号,pp.658-665,1990.3

3）菊地 優, 田村和夫, 前林和彦, 金子美香 : 高減衰積層ゴムの復元力特性 に関する研究，日本建築学会大会学術講演梗概集（中国），B 構造 I ,pp.659-660, 1990.10

4）李傑,向井洋一,橘英三郎,井上 豊: 高減衰積層ゴムを用いた免震支承 の復元力特性が建物の応答に及ぼす影響について(DOUBLE-TARGETモデ ルとそのSENSITIVITY)，日本建築学会大会学術講演梗概集 (東海)，B構 造 I ,pp.777-778, 1994.9

5）大鳥靖樹,石田勝彦:高堿衰積層ゴムの最大経験ひずみ依存性が免震構造
物の地震時応答に与える影響に関する研究,日本建築学会構造系論文集， 第 472 号, pp.75-84, 1995.6

6）柴田耕一, 高橋 勤, 笹川考義,一ノ瀬博明: 免震用積層ゴムの振動特性 に関する研究 履歴復元力特性のモデル化と非線形振動特性,日本建築学 会構造系論文集, 第475号,pp.515-516,1997.9

7）菊地 優 : 鉛プラグ入り積層ゴムの復元力モデルに関する研究，日本建 築学会大会学術講演梗概集 (関東) , B構造 I ,pp.659-660,1990.10

8）多田英之, 竹内 徹, 長谷川久巳, 早川邦夫 : 大容量免震ダンパ一の基本 性状に関する研究, 日本建築学会大会学術講演梗概集 (中国), B構造 I ,pp.673-674, 1990.10

9）森田慶子, 高山峰夫, 安藤勝利 : U型鉛ダンパーの降伏耐力に関する考察 (その 1 )変位・速度依存性について, 日本建築学会大会学術講演梗概集 (近畿), B-2構造 II , pp.729-730, 1996.9

10）高山盽夫, 森田慶子, 安藤勝利 : U型鉛ダンパーの降伏耐力に関する考察 (その 2 ) 降伏耐力と直径の関係について, 日本建築学会大会学術講演梗概 集 (近畿)，B-2 構造II ,pp.731-732, 1996.9

11）三輪晋也, 木村正彦, 小嶋英治, 林田敏弘 : 高減衰積層ゴムを使用した実 免震建物のシステム同定例, 日本建築学会大会学術講演梗概集 (中国), B 構造 I ,pp.633-634, 1990.10

12）久保田宗穗, 中山晋吾, 和田 章: 免震構造物（郵政省WESTビル）の兵 庫県南部地震における吸収エネルギー算定方法についての考察, 日本建築 学会大会学術講演梗概集 (近畿)，B-2構造 II ,pp.795-796,1996.9

13）中村 充, 竹脇 出, 安井 譲, 栘井 健, 金子正孝, 上谷宏次: 京都市 内に位置する免震建物における地震観測, 日本建築学会大会学術講演梗概 集 (関東) ,B-2構造 II ,pp.565-566, 1997.9

14）斎藤芳人, 森下真行, 藤波健剛, 龍神弘明: 免震建屋における地震観測結 果とその解析的検討 (その 2 .免震装置の復元力特性)，日本建築学会大 会学術講演会梗概集 (中国)，B-2 構造 II，pp.603-604，1999.9

15) Stewart, J. P., Conte, J. P., Aiken, I. D. "Observed Behavior of Seismically Isolated Buildings”, J. Struct. Engrg., ASCE, 125(9), pp.955-964, 1999.9

16) Sano, N., Matsushita, T., Furukawa, T., Inoue, Y. "Syst em Identification of Base Isolated Structure by Extended Kalman Filter using Recorded Seismic Response Data form Hyogoken Nanbu Earthquake", Proc. of the Second World Conf. on Struct. Control, Wiley, Vol.(3), pp.2159-2166, 1999.7

17) Nagarajaiah, S., Xiaohong, S. "Response of Base-Isolated USC Hospital Building in Northridge Earthquake",J. Struct. Engrg, ASCE, 126(10), pp.1177-1186, 2000.10

18) Chaudhary, M. T. A., Abe, M., Fujino, Y., Yoshida, J."System Identification of Two Base Isolated Bridges Using Seismic Records”, J. Struct. Engrg., ASCE, 126(10),pp. 1187-1195, 2000. 10

19）（財)日本建築センター : 免震構造建築物 - その技術開発と地震観測結果 PART2-, (財) 日本建築センター, 1995.7

20）伊澤清治, 大西良広, 樀英三郎, 井上豊: 兵庫県南部地震における免震建 物の観測記録と応答解析の比較，第 10 回日本地震工学シンボジウム， Vol.3,pp.2895-2900, 1998.11

21）建築技術編 : 制震・免震マルチガイド, 建築技術, pp.30-31，1997

22）古川忠稔,橘英三郎, 井上 豊: 予测誤差法による構造物の動的非線形特 性の推定 - バイリニア多層系せん断モデルの同定 - , 構造工学論文集 Vol.44B,pp.375-384, 1998.3

23) Ljung, L."System Identification Theory for the users", Prentice Hall, 87-88., 1987

24）中川 徹,小柳義夫:最小二乗法による実験デー夕解析,東京大学出版会 , 1995

25) Furukawa, T., Ito, M., Inoue, Y. "System Identification of Base Isolated Structure By Prediction Error Method Using Recorded Seismic Response Data Under Hyogoken-Nanbu Earthquake", Proc. 12th World Conf. on Earthquake Engrg. , Auckland, New Zealand, No.432, CD-ROM, 2000.1

26）和田 章,木下雅彦:MSSモデルを用いた柱降伏型の建物の立体振動解析 (その 1 ), (その 2 ), 日本建築学会大会学術講演梗概集, B構造 I,pp.313316,1985

27）和田 章,広瀬景一: 2 方向地振動を受ける無限均等ラーメン構造の弾塑 性応答性状, 日本建築学会構造系論文集, 第 399 号, pp.37-48, 1989.5 